\title{
Characterization of Fine Particulate Matter (PM) and secondary PM Precursor Gases in the Mexico City Metropolitan Area
}

A collaborative project among University of Colorado, Boulder (J.L. Jimenez), Massachusetts Institute of Technology/University of California, San Diego (L.T. Molina and M.J. Molina), Aerodyne Research, Inc. (C.E. Kolb)

\section{Final Report}

\section{Prepared By}

Jose L. Jimenez, Principal Investigator

University of Colorado-Boulder

UCB 216

Boulder, CO 80309-0216

\section{Prepared For}

Ashley Williamson

Atmospheric Science Program

Division SC-23.3

U.S. Department of Energy

Germantown, MD

May 18, 2009 


\section{DOE Research Grant Final Report}

Date of Report: 5/18/2008

DOE Grant Number: DE-FG02-05ER63981

Title: Characterization of Fine Particulate Matter (PM) and secondary PM Precursor

Gases in the Mexico City Metropolitan Area

Principal Investigators: Jose-Luis Jimenez

Institution: University of Colorado-Boulder

Project Period: 1/1/05 - 12/31/07 (plus no cost extension till 12/31/08)

Total Funded Amount: \$220,764

\section{Summary}

The objectives of this funded project were (a) to further analyze the data collected by our group and collaborators in Mexico City during the MCMA-2003 field campaign, with the goal of further our understanding of aerosol sources and processes; and (b) to deploy several advanced instruments, including the newly developed high-resolution time-offlight aerosol mass spectrometer (HR-ToF-AMS) and thermal-denuder (TD), during the MILAGRO/MAX-Mex/MCMA-2006 field campaign, and to analyze those data (together with the 2003 data) to provide additional insights on the formation and transformation of aerosols in the Mexico City area. These goals were addressed in collaboration with our project partners, MIT/Molina Center, and Aerodyne Research. Overall this project was very successful, resulting on 22+ journal papers including six "highly cited papers" and three papers that are the most cited in their respective journals (out of several thousand papers) since the year in which they were published. Multiple discoveries, such as the the underestimation of SOA in urban areas even for short photochemical ages, the demonstration that urban POA is of similar or higher volatility than urban SOA, and the first analysis of organic aerosol elemental composition in real-time have been recently published. Several dozen presentations at major US and international conferences and seminars also acknowledged this grant.

\section{$\underline{\text { Key Activities and Results }}$}

\section{(a) Analysis of MCMA-2003 field campaign data}

The analysis of MCMA-2003 data has been very fruitful, leading to the publication of 10 papers plus an additional paper which is currently under peer-review. Several important results include: (1) the first unequivocal demonstration that anthropogenic VOCs produce much larger amounts of secondary organic aerosols (SOA) in urban areas than predicted with current models [Volkamer et al., GRL, 2006]; (2) a thorough description of the aerosol concentration and physical and chemical properties in the MCMA and a comparison with previous campaigns, confirming the dominance of organic species, the local formation of ammonium nitrate, and the regional formation and transport of sulfate [Salcedo et al., ACP, 2006]; (3) the characterization of the dynamics, sources, and possible sinks of polycyclic aromatic hydrocarbons (PAHs) in Mexico City, and the first 
field intercomparison of three different methods to measure these species [Marr et al., $A C P, 2006] ;$ (4) the development of a method to quantify PAHs from the AMS and the identification of some very reactive PAHs that may be destroyed by ozone during filter sampling, but that were detected by the AMS [Dzepina et al., IJMS, 2006]; (5) the confirmation that the measured inorganic species appear to be in equilibrium with the gas-phase, and the characterization of the expected concentrations of $\mathrm{HCl}$ in the Mexico City atmosphere and their influence in aerosol chloride [San Martini et al., ACP, 2006]; (6) the characterization of the particle collection efficiency and beam focusing efficiency of the Aerodyne AMS using a Beam Width Probe (BWP) in the field for the first time [Salcedo et al., ACP, 2007]; (7) and overview / review of the findings related to fine particles from the MCMA-2003 campaign, and also including some new data on nanoparticle composition [Molina et al., ACP, 2007]; (8) an overview of the concentration and composition of non-refractory inorganic and organic aerosols in the Northern Hemisphere including our Mexico City results, showing that organic aerosols (OA) represent a significant fraction of the fine PM mass at all locations, and that oxygenated OA (OOA, an SOA surrogate at most locations), represents the majority of the mass even in urban areas [Zhang et al., GRL, 2007]; (9) the demonstration that there is a missing sink for gas-phase glyoxal in Mexico City which correlates with aerosol surface area, which leads to SOA formation accounting for about $15 \%$ of the observed SOA [Volkamer et al., GRL, 2007]; (10) the first published intercomparison of AMS with PIXE and PESA showing good a comparison for sulfate during most of the campaign, and evaporation losses of OA and ammonium chloride during PIXE analysis [Johnson et al., ES\&T, 2008]; (11) a reanalysis of the SOA formation case study of Volkamer et al. [2006] using several recently-proposed SOA models, which allow reaching mass closure but still leave many open questions about the sources and processes that lead to the observed SOA formation [Dzepina et al., ACPD, 2009] (see Figure 1 below).
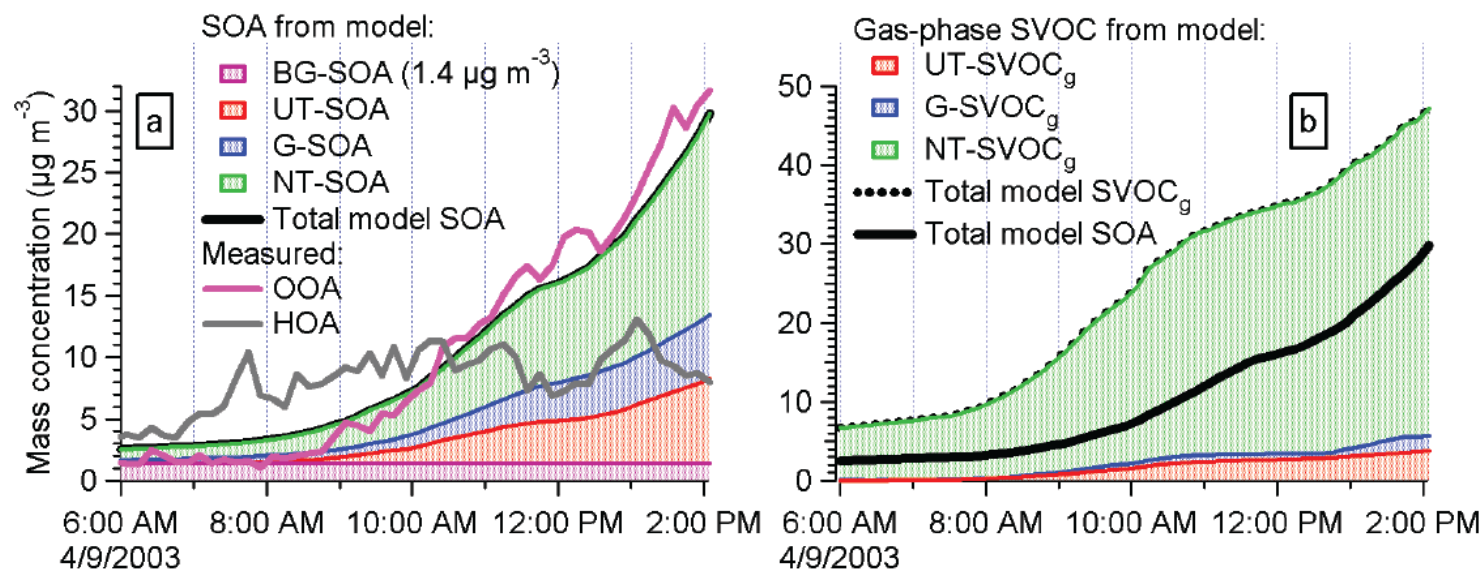

Figure 1. Total model SOA and gas-phase SVOC for the base case of Dzepina et al. [ACPD, 2009]. Part (a) shows the contributions of each model to the total model SOA, and (b) shows the contributions to the total model gas-phase. 


\section{(b) MILAGRO/MAX-Mex/MCMA-2006 field campaign and data analysis}

The Jimenez group participated in the MILAGRO/MAX-Mex/MCMA-2006 field campaign by deploying several advanced instruments at the T0 / IMP Supersite. The main instrument was a high-resolution time-of-flight aerosol mass spectrometer (HRToF-AMS) of which this was only the second ever field deployment (the first one having been also carried out by our group in Riverside, as described in Docherty et al., ES\&T, 2008). The HR-ToF-AMS was operated in V/W mode alternation for the first time following the development of this mode early in the campaign, and this mode has since become standard for the more than 20 HR-ToF-AMSs around the world. We also deployed a scanning mobility particle sizer (SMPS), a nano-SMPS, a thermal denuder, a particle concentrator, and a TSI DustTrak. The instruments performed very well during most of the campaign, and produced a very rich dataset of aerosol concentration and physical and chemical properties.

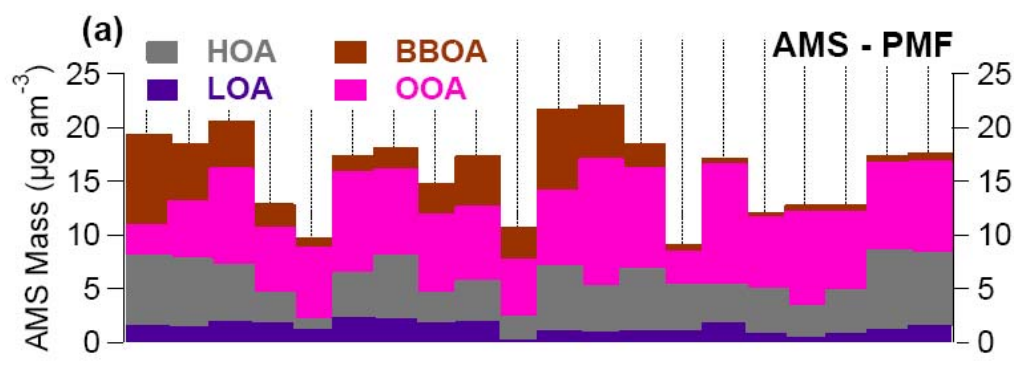

(c)
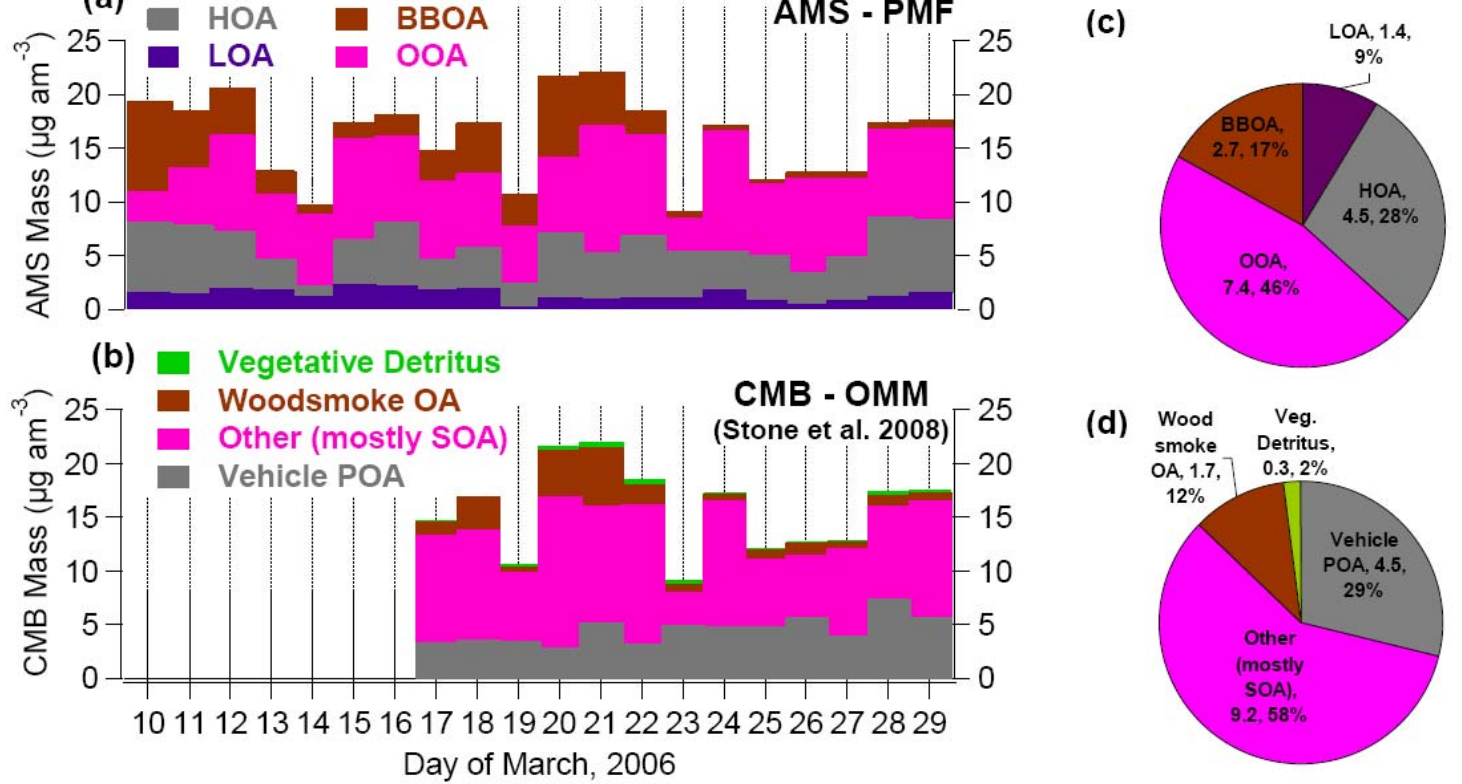

Figure 2. Daily source apportionment of OA from (a) PMF-AMS and (b) CMB-OMM with $(c, d)$ the average composition of each, respectively, for the overlapping sampling period from 17-30 March, 2006. Note: CMB-OMM OC results converted to OM (from Aiken et al., ACPD, 2009).

Results from the analysis of this dataset have been presented in four publications, one paper in press, and five papers currently under review, with several additional papers in preparation. Some key results include: (1) a thorough characterization of the composition of submicron particles at T0 during MILAGRO, with similar overall results to IMADAAVER in 1997 and MCMA-2003, and including the first application of PMF to highresolution AMS OA spectra, which compared well to source apportionment of OA using chemical mass balance of organic molecular markers performed by the Schauer group [Aiken et al., ACPD, 2009] (see Figure 2 above); (2) an analysis of the elemental 
composition of organic aerosols at T0 which is the first ever characterization of this property with high time resolution and that showed that $\mathrm{O} / \mathrm{C}$ is lowest during the rush hour period in the morning and highest during the photochemical peak in the afternoon [Aiken et al., ES\&T, 2008] (see Figure 3 below); (3) a demonstration of the thermaldenuder + AMS (TD-AMS) technique for chemically-resolved aerosol volatility measurements, including comparisons of laboratory and Mexico City data [Huffman et al., AS\&T, 2008]; (4) a demonstration that OOA and $\mathrm{O}_{\mathrm{x}}$ form at similar rates in polluted urban air, making $\mathrm{O}_{\mathrm{x}}$ a better tracer than $\mathrm{O}_{3}$ due to the removal of the NO titration effect, and allowing the use of the ratio of OOA and Ox formation rates as a target for photochemical models [Herndon et al., GRL, 2008]; (5) an analysis of the sources and sinks of $\mathrm{HNO}_{3}$ in Mexico City, showing the importance of the $\mathrm{NH}_{4} \mathrm{NO}_{3}$ equilibrium, reactive loss of $\mathrm{HNO}_{3}$ to dust, and dry deposition of $\mathrm{HNO}_{3}$ in the mass balance of that species [Zheng et al., ACP, 2008]; (6) an analysis of the factors controlling light scattering an absorption in Mexico City, which showed very good correlation between AMS mass and submicron scattering, and demonstrated that secondary species account for $70 \%$ of the mass and scattering on the late afternoon [Paredes-Miranda et al., ACP, 2009]; (7) the first detailed analysis of chemically-resolved volatility of inorganic and organic aerosols in the field, showing that all types of OA are semivolatile and that POA is of similar or higher volatility as OOA/SOA, with the most aged OOA/SOA showing the lowest volatility [Huffman et al., ACP, 2009]; (8) an analysis of the volatility of POA from various sources of potential importance during MILAGRO, all of which showed a semivolatile character although with a wide range of variation [Huffman et al., ES\&T, 2009]; (9) a comparison of the PMF-AMS results with the output of two regional models (WRF-CHEM and CHIMERE) showing that POA is reasonably well-predicted in Mexico City as well as a significant contribution of biogenic SOA to the regional background in Central Mexico [Fast et al., ACPD, 2009; Hodzic et al., ACPD, 2009].

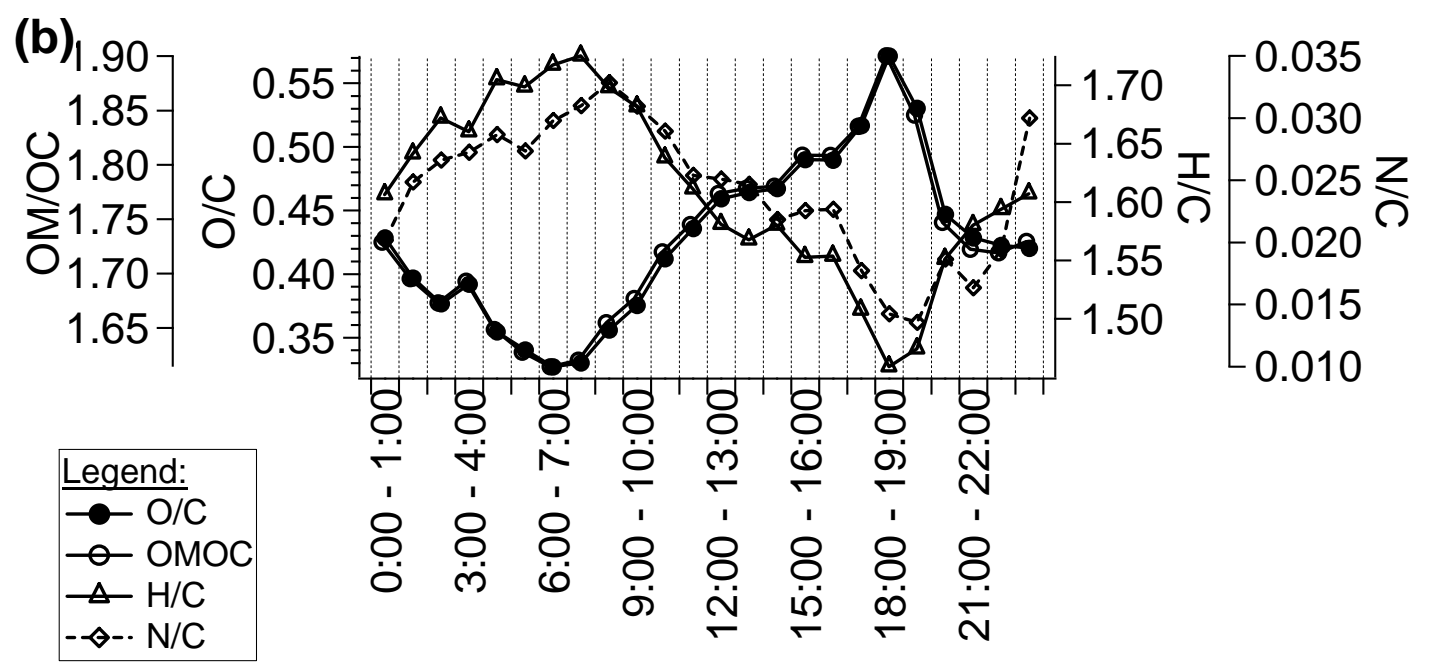

Figure 3. Diurnal averages of atomic O/C, H/C and N/C and OM/OC sampled at the TO ground site in Mexico City during MILAGRO. 


\section{Publications Acknowledging this Grant}

We have published the 14 peer-reviewed papers on our research in this project, while one paperwebwebelements is "in press" and 7 more are undergoing peer-review. The results of this project have been received with very high interest by the scientific community: these papers have already been cited 353 times (from ISI Web of Science). Six (6) of these papers are classified as "Highly Cited Papers" (Top 1\% in citations in their journals) by ISI. Finally, 3 of them are the most cited paper in Geophysical Research Letters since 2006 (of 5085 papers), the most cited paper in Geophysical Research Letters since 2007 (of 3382 papers), and the most cited paper in Environmental Science and Technology since 2008 (of 2099 papers).

\section{Papers published (14):}

D. Salcedo, T. B. Onasch, K. Dzepina, M. R. Canagaratna, Q. Zhang, J.A. Huffman, P. F. DeCarlo, J. T. Jayne, P. Mortimer, D. R. Worsnop, C. E. Kolb, K. S. Johnson, B. Zuberi, L. C. Marr, R. Volkamer, L. T. Molina, M. J. Molina, B. Cardenas, R. M. Bernabé, C. Márquez, J. S. Gaffney, N. A. Marley, A. Laskin, V. Shutthanandan, Y. Xie, W. Brune, R. Lesher, T. Shirley, and J. L. Jimenez. Characterization of ambient aerosols in Mexico City during the MCMA-2003 campaign with Aerosol Mass Spectrometry: results from the CENICA Supersite. Atmos. Chem. Phys., 6, 925-946, 2006.

- Cited 57 times, "Highly Cited Paper" (from ISI Web of Science)

L. C. Marr, K. Dzepina, J. L. Jimenez, F. Riesen, H. L. Bethel, J. Arey, J. S. Gaffney, N. A. Marley, L. T. Molina, M. J. Molina. Sources and transformations of particle-bound polycyclic aromatic hydrocarbons in Mexico City. Atmos. Chem. Phys., 6, 1733-1745, 2006.

- Cited 20 times (from ISI Web of Science)

R. Volkamer, J.L. Jimenez, F. San Martini, K. Dzepina, Q. Zhang, D. Salcedo, L.T. Molina, D.R. Worsnop, and M.J. Molina. Secondary Organic Aerosol Formation from Anthropogenic Air Pollution: Rapid and Higher than Expected. Geophys. Res. Lett., 33(17), L17811, 2006.

- Cited 109 times, "Highly Cited Paper” (from ISI Web of Science)

- Most cited of any papers published in GRL since 2006

F.M. San Martini, E.J. Dunlea, R. Volkamer, T.B. Onasch, J.T. Jayne, M.R. Canagaratna, D. R. Worsnop, C.E. Kolb, J.H. Shorter, S.C. Herndon, M.S. Zahniser, D. Salcedo, K. Dzepina, J.L. Jimenez, J. M. Ortega, K.S. Johnson, G.J. McRae, L.T. Molina, M.J. Molina. Implementation of a Markov Chain Monte Carlo Method to Inorganic Aerosol Modeling of Observations from the MCMA-2003 Campaign. Part II: Model Application to the CENICA, Pedregal and Santa Ana Sites. Atmos. Chem. Phys., 6, 4889-4904, 2006.

- Cited 8 times (from ISI Web of Science) 
K. Dzepina, J. Arey, L.C. Marr, D.R. Worsnop, D. Salcedo, Q. Zhang, T.B. Onasch, L.T. Molina, M.J. Molina, and J.L. Jimenez. Detection of Particle-Phase Polycyclic Aromatic Hydrocarbons in Mexico City using an Aerosol Mass Spectrometer. International Journal of Mass Spectrometry, 263(2-3), 152-170, 2007.

- Cited 8 times (from ISI Web of Science)

D. Salcedo, T. B. Onasch, M. R. Canagaratna, K. Dzepina, J. A. Huffman, J. T. Jayne, D. R. Worsnop, C. E. Kolb, S. Weimer, F. Drewnick, J. D. Allan, A. E. Delia and J. L. Jimenez. Technical note: use of a beam width probe in an Aerosol Mass Spectrometer to monitor particle collection efficiency in the field. Atmos. Chem. Phys., 7, 549-556, 2007.

- Cited 11 times (from ISI Web of Science)

L.T. Molina, C.E. Kolb, B. de Foy, B.K. Lamb, W.H. Brune, J.L. Jimenez, R. RamosVillegas, J. Sarmiento, V. H. Paramo-Figueroa, B. Cardenas, V. Gutierrez-Avedoy, and M. J. Molina. Air Quality in North America’s Most Populous City - Overview of MCMA-2003 Campaign. Atmos. Chem. Phys., 7, 2447-2473, 2007.

- Cited 28 times, "Highly Cited Paper” (from ISI Web of Science)

Q. Zhang, J.L. Jimenez, M.R. Canagaratna, J.D. Allan, H. Coe, I. Ulbrich, M.R. Alfarra, A. Takami, A.M. Middlebrook, Y.L. Sun, K. Dzepina, E. Dunlea, K. Docherty, P.F. DeCarlo, D. Salcedo, T. Onasch, J.T. Jayne, T. Miyoshi, A. Shimono, S. Hatakeyama, N. Takegawa, Y. Kondo, J. Schneider, F. Drewnick, S. Weimer, K. Demerjian, P. Williams, K. Bower, R. Bahreini, L. Cottrell, R.J. Griffin, J. Rautiainen, and D.R. Worsnop. Ubiquity and Dominance of Oxygenated Species in Organic Aerosols in Anthropogenically-Influenced Northern Hemisphere Mid-latitudes. Geophys. Res. Lett., 34, L13801, doi:10.1029/2007GL029979.

- Cited 71 times, “Highly Cited Paper” (from ISI Web of Science)

- $\quad$ Most cited of any papers published in GRL since 2007

R. Volkamer, F. San Martini, L.T. Molina, D. Salcedo, J.L. Jimenez, M.J. Molina. A Missing Sink for Gas-Phase Glyoxal in Mexico City: Formation of Secondary Organic Aerosol. Geophys. Res. Lett., 34, L19807, doi:10.1029/2007GL030752, 2007.

- Cited 23 times, “Highly Cited Paper” (from ISI Web of Science)

J.A. Huffman, P.J. Ziemann, J.T. Jayne, D.R. Worsnop, and J.L. Jimenez. Development and Characterization of a Fast-Stepping/Scanning Thermodenuder for ChemicallyResolved Aerosol Volatility Measurements. Aerosol Science and Technology, 42:395407, 2008.

- Cited 3 times (from ISI Web of Science)

A.C. Aiken, P.F. DeCarlo, J.H. Kroll, D.R. Worsnop, J.A. Huffman, K. Docherty, I.M. Ulbrich, C. Mohr, J.R. Kimmel, D. Sueper, Q. Zhang, Y. Sun, A. Trimborn, M. Northway, P.J. Ziemann, M.R. Canagaratna, T.B. Onasch, R. Alfarra, A.S.H. Prevot, J. Dommen, J. Duplissy, A. Metzger, U. Baltensperger, and J.L. Jimenez. O/C and OM/OC Ratios of Primary, Secondary, and Ambient Organic Aerosols with High Resolution 
Time-of-Flight Aerosol Mass Spectrometry. Environ Sci. Technol., 42, 4478-4485, doi: 10.1021/es703009q, 2008.

- Cited 18 times, "Highly Cited Paper" (from ISI Web of Science)

- Most cited of any papers published in ES\&T since 2008

S.C. Herndon, T.B. Onasch, E.C. Wood, J.H. Kroll, M.R. Canagaratna, J.T. Jayne, M.A. Zavala, W.B. Knighton, C. Mazzoleni, M.K. Dubey, I.M. Ulbrich, J.L. Jimenez, R. Seila, J.A. de Gouw, B. de Foy, J. Fast, L.T. Molina, C.E. Kolb and D.R. Worsnop. The Correlation of Secondary Organic Aerosol with Odd Oxygen in a Megacity Outflow. Geophys. Res. Lett., 35, L15804, doi:10.1029/2008GL034058, 2008.

- Cited 3 times (from ISI Web of Science)

J. Zheng, R. Zhang, E.C. Fortner, R.M. Volkamer, L.T. Molina, A.C. Aiken, J.L. Jimenez, K. Gäggeler, J. Dommen, S. Dusanter, P.S. Stevens, and X. Tie. Measurements of HNO3 and N2O5 Using Ion Drift - Chemical Ionization Mass Spectrometry during the MILAGRO/MCMA -2006 Campaign. Atmos. Chem. Phys., 8, 6823-6838, 2008.

- Cited 2 times (from ISI Web of Science)

K.S. Johnson, A. Laskin, J.L. Jimenez, V. Shutthanandan, L.T. Molina, D. Salcedo, K. Dzepina, M.J. Molina. Comparative analysis of urban atmospheric aerosol by ProtonInduced X-ray Emission (PIXE), Proton Elastic Scattering Analysis (PESA), and Aerosol Mass Spectrometry (AMS). Environ Sci. Technol., 42, 6619-6624, 2008. doi: 10.1021/es800393e.

Papers in press (1):

G. Paredes-Miranda, W.P. Arnott, J.L. Jimenez, A.C. Aiken, J.S. Gaffney, and N.A. Marley. Primary and Secondary Contributions to Aerosol Light Scattering and Absorption in Mexico City During the MILAGRO 2006 Campaign. Atmos. Chem. Phys., in press, Apr. 2009.

\section{Papers under peer-review (7):}

J.A. Huffman, K.S. Docherty, A.C. Aiken, M.J. Cubison, I.M. Ulbrich, P.F. DeCarlo, D. Sueper, J.T. Jayne, D.R. Worsnop, P.J. Ziemann and J.L. Jimenez. Chemically-Resolved Aerosol Volatility Measurements from Two Megacity Field Studies. Atmos. Chem. Phys. Discuss., 9, 2645-2697, 2009.

K. Dzepina, R.M. Volkamer, S. Madronich, P. Tulet, I.M. Ulbrich, Q. Zhang, C.D. Cappa, P.J. Ziemann, and J.L. Jimenez. Evaluation of New Secondary Organic Aerosol Models for a Case Study in Mexico City. Atmos. Chem. Phys. Discuss., 9, 4417-4488, 2009.

A.C. Aiken, D. Salcedo, M.J. Cubison, J.A. Huffman, P.F. DeCarlo, I.M. Ulbrich, K.S. Docherty, D. Sueper, J.R. Kimmel, D.R. Worsnop, A. Trimborn, M. Northway, E.A. 
Stone, J.J. Schauer, R. Volkamer, E. Fortner, B. de Foy, J. Wang, A. Laskin, V. Shutthanandan, J. Zheng, R. Zhang, J. Gaffney, N. Marley, G. Paredes-Miranda, W.P. Arnott, L.T. Molina, G. Sosa, and J.L. Jimenez. Mexico City Aerosol Analysis during MILAGRO using High Resolution Aerosol Mass Spectrometry at the Urban Supersite (T0). Part 1: Fine Particle Composition and Organic Source Apportionment. Atmos. Chem. Phys. Discuss., 9, 8377-8427, 2009.

J. Fast, A.C. Aiken, L. Alexander, T. Campos, M.R. Canagaratna, E. Chapman, P.F. DeCarlo, B. de Foy, J. Gaffney, J. de Gouw, J.C. Doran, L. Emmons, A. Hodzic, S.C. Herndon, G. Huey, J.T. Jayne, J.L. Jimenez, L.Kleinman, W. Kuster, N. Marley, C. Ochoa, T.B. Onasch, M. Pekour, C. Song, I.M. Ulbrich, C. Warneke, D. Welsh-Bon, C. Wiedinmyer, D.R. Worsnop, X.Y. Yu, and R. Zaveri. Evaluating Simulated Primary Anthropogenic and Biomass Burning Organic Aerosols during MILAGRO: Implications for Assessing Treatments of Secondary Organic Aerosols. Atmos. Chem. Phys. Discuss., 9, 4769-4804, 2009.

J.A. Huffman, K.S. Docherty, C. Mohr, M.J. Cubison, I.M. Ulbrich, P.J. Ziemann, T.B. Onasch, and J.L. Jimenez. Chemically-Resolved Volatility Measurements of Organic Aerosol from Different Sources. Environ Sci. Technol., submitted, Dec. 2008.

A. Hodzic, J.L. Jimenez, S. Madronich, A.C. Aiken, B. Bessagnet, G. Curci, J. Fast, J.F. Lamarque, T.B. Onasch, G. Roux, I.M. Ulbrich. Modeling organic aerosols during MILAGRO: application of the CHIMERE model and importance of biogenic secondary organic aerosols. Atmos. Chem. Phys. Discuss., submitted, May. 2009. 